\title{
Identification and characterization of novel B-cell epitopes within EBV latent membrane protein 2 (LMP2)
}

\author{
Xiangyang Xue*, Shanli Zhu, Wenshu Li, Jun Chen, Qin Ou, Meixia Zheng, Wenci Gong, Lifang Zhang \\ From Institut Pasteur International Network Annual Scientific Meeting \\ Hong Kong. 22-23 November 2010
}

The purpose of this study was to screen and identify the linear B cell epitopes of Epstein-Barr virus (EBV) latent membrane protein 2 (LMP2). The secondary structure and the surface properties of EBV LMP2A protein were analyzed. Then, the peptides with good hydrophilicity, high accessibility and flexibility and strong antigenicity were chosen and average antigenicity index (AI) of epitope peptide was further investigated. Three peptides were selected as potential linear B cell epitopes. The location and the sequence of amino acid were 199-209 (RIEDPPFNSLL), 318-322 (TLNLT) and 381-391 (KSLSSTEFIPN), respectively. The genes encoding potential B cell epitope were cloned and expressed in E. coli system. The immune sera of above different purified fusion proteins were obtained from $\mathrm{BLAB} / \mathrm{c}$ mice by subcutaneously immunization for three times. Western blot showed that these epitope recombinant proteins could be recognized by the serum antibodies against the whole LMP2 of EBV obtained from nasopharyngeal carcinoma (NPC). Indirect ELISA measured the reactivity of individual sera from 196 NPC patients, 44 infectious mononucleosis (IM) and 108 healthy individuals to these epitope-fused proteins indicated that NPC patients were significantly higher compared with IM and healthy individuals $(P<0.05)$. In addition, all the immune sera of peptide-fused proteins could response to native LMP2A antigen obtained from the EBV prototype strain, B95-8 cells. IFA confirmed that the recognition of the specific antibodies induced by the immune sera of epitope peptide-fused proteins was intracellular regions of LMP2A. These results demonstrated that these three predictive epitopes not only were immunodominant B-cell epitopes of LMP2A, but also may be

Department of Microbiology and Immunology, Wenzhou Medical College, Wenzhou, Zhejiang 325035, PR China

\section{Ciomed Central}

C 2011 Xue et al; licensee BioMed Central Ltd. This is an open access article distributed under the terms of the Creative Commons Attribution License (http://creativecommons.org/licenses/by/2.0), which permits unrestricted use, distribution, and reproduction in any medium, provided the original work is properly cited. potential targets for application in the design of diagnostic tools.

Published: 10 January 2011

doi:10.1186/1753-6561-5-S1-P31

Cite this article as: Xue et al:: Identification and characterization of novel B-cell epitopes within EBV latent membrane protein 2 (LMP2). BMC Proceedings 2011 5(Suppl 1):P31.

Submit your next manuscript to BioMed Central and take full advantage of:

- Convenient online submission

- Thorough peer review

- No space constraints or color figure charges

- Immediate publication on acceptance

- Inclusion in PubMed, CAS, Scopus and Google Scholar

- Research which is freely available for redistribution 